Tersedia online di: http://ejournal-balitbang.kkp.go.id/index.php/JP
e-mail:jurnalpari@gmail.com
JURNAL PARI
volume 5 Nomor 1 Juli 2019
p-ISSN: 2502-0730
e-ISSN : 2549-0133

\title{
BELUM EFEKTIF TERHADAP SISTEM PENGELOLAAN KEARSIPAN OLEH APARATUR SIPIL NEGARA, PADA UNIT PELAKSANA TEKNIS SEKOLAH USAHA PERIKANAN MENENGAH SORONG, DI LINGKUNGAN KEMENTERIAN KELAUTAN DAN PERIKANAN
}

\author{
Arfa Fakaubun \\ Sekolah Usaha Perikanan Menengah Sorong \\ Diterima tanggal : 27 Mei 2019 Diterima setelah perbaikan : 23 Juni 2019 \\ disetujui terbit : 15 Juli 2019
}

\begin{abstract}
ABSTRAK
Telah dijelaskan dalam Undang-Undang Nomor 5 Tahun 2014 tentang Aparatur Sipil Negara dan Undang-Undang Nomor 43 Tahun 2009 tentang Kearsipan, bahwa dalam rangka pelaksanaan cita-cita bangsa dan mewujudkan tujuan negara serta mempertahankan Negara Kesatuan Republik Indonesia sebagaimana tercantum dalam Pembukaan Undang-Undang Dasar Negara Republik Indonesia Tahun 1945, bahwa perlu dibangun aparatur sipil negara yang memiliki integritas dan profesional mampu menyelenggarakan pelayanan publik bagi masyarakat terhadap pengelolaan arsip sebagai identitas dan jati diri bangsa, serta sebagai memori, acuan dan bahan pertanggungjawaban dalam kehidupan bermasyarakat, berbangsa dan bernegara yang harus dikelola dan diselamatkan oleh negara, yang sesuai dengan prinsip, kaidah, dan standar kearsipan sebagaimana yang dibutuhkan oleh suatu sistem penyelenggaraan kearsipan nasional yang andal. namun pada prinsipnya di Sekolah Usaha Perikanan Menengah Sorong Aparatur Sipil Negara belum efektif terhadap pengelolaan kearsipan yang baik.
\end{abstract}

\section{Kata Kunci : Kearsipan sebagai Sumber Informasi Pelayanan Publik}

\begin{abstract}
It has been explained in Law Number 5 of 2014 concerning State Civil Apparatus and Law Number 43 of 2009 concerning Archives, that in the framework of implementing the ideals of the nation and realizing the state's goals and maintaining the Unitary State of the Republic of Indonesia as stated in the Opening of the Law The State Fundamentals of the Republic of Indonesia in 1945, that it is necessary to develop a state of integrity and professional civil apparatus capable of holding public services for the public to manage records as national identity and identity, and as a memory, reference and material responsibility in the life of the community, nation and state must be managed and saved by the state, in accordance with the principles, rules, and archival standards as required by a system for the implementation of reliable national archives. but in principle in the Sorong Middle School Fisheries Business School the State Civil Apparatus has not been effective in managing good archives.
\end{abstract}

Keywords : Archives as a Source of Public Service Information 


\section{PENDAHULUAN}

Undang-Uindang Nomor 5 Tahun 2014 Tentang Aparatur Sipil Negara telah jelas mengatakan bahwa dalam rangka pelaksanaan cita-cita bangsa dan mewujudkan tujuan negara serta mempertahankan Negara Kesatuan Republik Indonesia, yang tercantum di dalam Undang-Undang Dasar Negara Republik Indonesia tahun 1945.

Sehubungan dengan bunyi undang-undang diatas, maka di katakan bahwa Aparatur Sipil Negara pada Sekolah Usaha Perikanan Menengah Sorong sudah seharusnya dan sepantasnya dapat mewujudkan tujuan negara dan mempertahankan Negara Kesatuan Republik Indonesia, dengan mengelola dan menjaga kestabilan kearsipan sebagai aset negara atau sebagai sejarah bagi bangsa dan negara Republik Indonesia.

Tapi kenyataannya sulit untuk dilaksanakan oleh aparatur sipil negara Sekolah Usaha Perikanan Menengah Sorong, karena mereka berfikir arsip itu hanya sekedar kertas yang tidak berarti. Padahal kalau di artikan arsip itu adalah sebagai aset negara yang tidak pernah terganti nilainya oleh apapun juga.

Sedangkan Undang-Undang Nomor 43 Tahun 2009 tentang Kearsipan sudah sangat benar penjelasannya, maka Pengertian Kearsipan adalah hal-hal yang berkaitan dengan arsip.

Arsip adalah rekaman kegiatan atau peristiwa dalam berbagai bentuk dan media sesuai dengan perkembangan teknologi informasi dan komunikasi yang dibuat dan diterima oleh lembaga negara, pemerintahan daerah, lembaga pendidikan, perusahaan, organisasi politik, organisasi kemasyarakatan, dan perseorangan dalam pelaksanaan kehidupan bermasyarakat, berbangsa dan bernegara.

Kearsipan merupakan proses atau kegiatan yang dimulai dari penciptaan, penerimaan, pengumpulan, pengaturan, pengendalian, pemeliharaan, perawatan, penyimpanan serta evaluasi menurut sistem tertentu yang ditentukan. Walaupun kegiatan kearsipan seringkali menyita tempat, tenaga sekaligus waktu, namun disisi lain informasi yang terkandung di dalam arsip sangatlah penting dan rentang hilang. Dari persoalan ini setiap organisasi harus memperhatikan sistem pengelolaan kearsipannya, dan apabila administrasi yang mengelola arsip diabaikan dan dianggap arsip itu tidak perlu penanganan khusus atau cukup disimpan pada komputer saja dan tanpa memperdulikan akibatnya, sudah tentu organisasi tersebut belum memahami maksud dan tujuan arsip.
Hal semacam ini yang terdapat pada Aparatur Sipil Negara Sekolah Usaha Perikanan Menengah Sorong, yang belum sepenuhnya mengelola arsip di unit-unut mereka dengan baik dan benar karena banyak arsip yang sering hilang dan tercecer sehingga pada saat di perlukan malah tidak ditemukan arsip tersebut. Itu yang dikatakan Belum Efekti terhadap pengelolaan Kearsipan.

Tujuan dari pengelolaan kearsipan adalah menyelenggarakan pengurusan arsip yang bermutu melalui program seleksi yang mantap secara efektif dan efisien sehingga tercipta kondisi kearsipan dalam suatu lembaga / instansi yang berkualitas.

Efektifitas kearsipan sangat dibutuhkan dalam pelaksanaan administrasi, karena arsip merupakan pusat ingatan bagi setiap kegiatan dalam suatu lembaga pemerintahan, tanpa arsip tidak mungkin seorang pegawai dapat mengingat semua catatan dan dokumen secara lengkap. Karena itu suatu lembaga dalam mengelola kearsipan haru memperhatikan sistem manajemen arsip yang sesuai dengan keadaan organisasi dalam mencapai tujuannya, jika sistem manajemen kearsipan dapat berjalan dengan baik, maka kegiatan administrasi dapat pula berjalan dengan baik dan efektif. Dan sebaliknya jika sistem manajemen kearsipan tidak diperhatikan dengan baik, maka kegiatan administrasi akan terhambat, hal ini pula yang membuat surat atau arsip maupun dokumen-dokumen yang sulit ditemukan bahkan tidak diketahui keberadaannya, sehingga surat atau arsip yang perlu ditindaklanjuti akhirnya tidak dapat ditindaklanjuti dikarenakan tidak tahu keberadaan dokumen tersebut.

Hal tersebut yang terdapat pada Sekolah Usaha Perikanan Menengah Sorong, dimana Aparatur Sipil Negara yang belum efektif dalam melaksanakan tugas sebagai pengelola administrasi berupa sistem manajemen kearsipan, namun hakekatnya kita tahu bahwa tugas Aparatur Sipil Negara adalah melayani dan menjaga dokumen-dokumen negara yang nantinya akan menjadi bukti pertanggung jawaban pada saat audit maupun sebagai bukti-bukti lainnya.

Arsip sangatlah penting dalam suatu organisasi seperti pada Sekolah Usaha Perikanan Menengah Sorong, karena arsip merupakan sumber informasi dan wahana dokumentasi serta alat bukti yang sah, maka arsip merupakan bahan atau data untuk pengambilan suatu keputusan secara tepat, dan arsip sebagai suatu sistem dimana satu sama lainnya saling berkaitan dalam suatu ikatan yang utuh, karena arsip dapat menunjang suatu program kegiatan organisasi, baik dari segi perencanaan, pelaksanan 
maupun pengendalian tugas organisasi yang berada di lembanga pendidikan.

Sumber informasi terekam yang memiliki fungsi yang sangat penting untuk menunjang proses kegiatan administrasi negara dan manajemen birokrasi, disamping itu arsip dapat pula dimanfaatkan oleh lembaga dan instansi, untuk mengatur pengelolaan arsip baik secara institusional maupun secara nasional. dan metode pengelolaan arsip yang di nilai memenuhi kebutuhan peningkatan efisiensi operasional instansi dan sekaligus kebutuhan pelestarian arsip yang di anggap memiliki nilai guna untuk kepentingan yang lebih luas, dalam rangka penyelenggaraan kehidupan berbangsa dan bernegara. Dalam hal ini dibutuhkan pengaturan mengenai pengelolaan arsip pada lembaga-lembaga atau organisasi pencipta arsip (creating agencies) agar dapat mengelola arsip secara efisien untuk kepentingan akuntabilitas dan untuk kepentingan kolektif bangsa dalam rangka pertanggung jawaban nasional.

Pengaturan secara nasional di perlukan dalam rangka pelestarian arsip sebagai memori kolektif bangsa agar dalam pengelolaan arsip keterkaitan dalam alur yang jelas antara lembaga-lembaga negara dan badan-badan pemerintah, baik dalam pengelolaan arsip dinamis maupun arsip statis.

Dalam pengelolaan arsip dinamis di perlukan adanya norma dan standar manajemen arsip yang berlaku secara nasional untuk menjamin bahwa penyusutan arsip yang berlaku untuk semua lembagalembaga negara dan badan-badan pemerintahan di lakukan dengan tolak ukur yang sama sehingga dapat di cegah adanya pemusnahan arsip yang tidak terkendali. Dengan demikian penyusutan arsip dapat di lakukan secara sistematis, terukur dan menghasilkan arsip statis yang berkualitas tinggi sebagai memori kolektif bangsa dan sebagai bukti pertanggung jawaban nasional kepada generasi yang akan datang.

Untuk itu di perlukan adanya alur yang jelas dalam penyusutan arsip baik pemindahan dari unit-unit pengolah ke unit kearsipan suatu lembaga pencipta arsip, pemusnahan arsip yang telah habis jangka waktu simpan dan nilai gunanya dan penyerahan arsip yang memiliki nilai guna permanen kepada lembaga kearsipan untuk di kelola sebagai arsip statis.

Pengaturan pengelolaan arsip statis secara nasional di perlukan untuk menjamin pelestarian memori kolektif bangsa secermat mungkin dan penggunaannya untuk kepentingan publik, serta penyelenggaraan kehidupan berbangsa dan bernegara. Hal itu di perlukan dalam rangka koordinasi kelembagaan secara nasional dan standar layanan kearsipan baik di lingkungan instansi-instansi pemerintah pusat maupun instansi perangkat daerah baik di lingkungan pemerintah provinsi maupun pemerintah kabupaten/kota. Dan di harapkan penyelenggaraan pengelolaan arsip yang efisien dan pelestarian serta pendayagunaan arsip yang efektif secara nasional.

Yang dimaksud dengan "peran dan kedudukan hukum arsiparis" adalah yang berhubungan dengan fungsi dan peran dalam kegiatan kearsipan sejak penciptaan sampai dengan penyusutan, dan sampai dengan pemanfaatan arsip, serta kegiatan lainnya yang dilindungi secara sah oleh peraturan perundangundangan.

Yang dimaksud dengan standar kualitas dan spesifikasi prasarana dan sarana kearsipan adalah ketentuan standar tentang kualitas, bahan, bentuk, ukuran, jenis, dan lain-lain yang dijadikan acuan atau pedoman dalam pengadaan dan penggunaan sara dan prasarana kearsipan.

Yang dimaksud dengan meningkatkan kualitas pelayanan publik adalah penyelenggaraan kearsipan yang komprehensif dan terpadu dengan dukungan sumber daya manusia yang profesional serta prasarana dan sarana yang memadai akan meningkatkan kualitas pelayanan publik dalam memanfaatkan arsip yang dibutuhkan melalui ketersediaan arsip yang faktual, utuh, sistematis, autentik, terpercaya, dan dapat digunakan.

\section{TINJAUAN PUSTAKA}

Ada beberapa pendapat yang dikemukakan oleh para ahli untuk memperoleh gambaran yang jelas mengenai pengertian kearsipan dan arsip adalah sebagai berikut :

Pengertian Kearsipan menurut Donni dan Agus (2013) yang berpendapat bahwa kearsipan adalah suatu aktifitas yang berhubungan dengan kegiatan pengelolaan arsip atau yang disebut dengan administrasi arsip.

Menurut Wursanto (1991) bahwa pengertian kearsipan adalah proses kegiatan pengurusan atau pengaturan arsip dengan mempergunakan suatu sistem tertentu, sehingga arsip-arsip dapat di temukan kembali dengan mudah dan cepat apabila sewaktuwaktu di perlukan. 
Sedangkan yang dikatakan oleh Sugiarto (2005) bahwa kearsipan merupakan dasar dari pemeliharaan surat mulai dari penyimpanan sampai penyusutan sehinga apabila diperlukan dapat ditemukan kembali.

Menurur Barto (2005) bahwa pengerian arsiparis adalah pusat ingatan, sumber informasi dan sebagai alat pengawasan yang sangat di perlukan dalam setiap organisasi dalam rangka kegiatan perencanaan.

Adapun pengertian kearsipan menurut Sedarmayanti (2008) bahwa kearsipan adalah kegiatan mengatur dan menyusun arsip dalam suatu tatanan yang sistematis dan logis, berupa menyimpan, serta merawat arsip untuk digunakan secara aman dan ekonomis.

Dari defenisi diatas, dapat disimpulkan bahwa kerasipan merupakan proses dari awal bentuknya surat/warkat serta penyimpanan hingga penyusutan arsip yang dilakukan dan disimpan untuk kemungkinan dipergunakan pada waktu yang akan datang.

Menurut Gie (1996) di dalam bukunya Administrasi Perkantoran Moderen yang berbunyi bahwa arsip adalah kumpulan dokumen yang disimpan secara sistematis agar setiap diperlukan dapat ditemukan kembali secara cepat dan tepat.

Di dalam Undang-Undang bahwa naskah-naskah yang berisikan hal-hal yang terhubung satu dengan yang lainnya di himpun dalam suatu berkas tersendiri mengenai masalah yang sama.

Sedangkan menurut Suraja (2006) bahwa pengertian arsip adalah naskah atau catatan yang dibuat dan di terima oleh suatu organisasi pemerintah, swasta dan perorangan mengenai suatu peristiwa atau hak dalam kehidupannya, dalam bentuk apapun baik dalam keadaan tunggal maupun berkelompok yang memiliki nilai guna tertentu, dan di simpan secara sistematis sehingga bilamana di perlukan dapat di temukan dengan mudah dan cepat.

Menurut fungsi dan kegunaannya arsip dapat di golongkan menjadi arsip dinamis dan arsip statis yang menurut undang-undang nomor 7 tahun 1971 yang di maksud dengan arsip dinamis dan arsip statis adalah sebagai berikut :

1. Arsip dinamis yang di gunakan secara langsung dalam perencanaan, pelaksanaan, penyelenggaraan kehidupan kebangsaan pada umumnya atau di pergunakan secara langsung dalam penyelenggaraan administrasi negara. Yang dapat di katakan bahwa arsip dinamis adalah arsiparsip yang di pergunakan secara langsung dalam kegiatan perkantoran sehari-hari. Arsip dinamis dapat di rincikan sebagai berikut :

- Arip aktif adalah arsip yang masih di pergunakan secara terus menerus bagi kelangsungan pekerjaan di lingkungan unit pengolah bagi suatu organisasi perkantoran

- Arsip inaktif adalah arsip yang tidak lagi dipergunakan secara terus menerus atau frekuensi penggunaannya sudah jarang atau hanya di pergunakan sebagai referensi.

2. Arsip statis adalah arsip yang tidak di pergunakan secara langsung untuk perencanaan, penyelenggaraan kehidupan kebangsaan pada umumnya maupun untuk penyelenggaraan kehidupan sehari-hari sebagai administrasi negara, dan ini merupakan pertanggung jawaban nasional bagi kegiatan pemerintah dan nilai gunanya penting untuk generasi yang akan datang.

Menurut Choiriyah (2007) arsip adalah warkat yang merupakan setiap catatan tertulis baik dalam bentuk gambar ataupun bagang yang memuat keteranganketerangan mengenai suatu objek/pokok persoalan maupun suatu peristiwa yang dibuat orang untuk membantu daya ingat orang.

Dari defenisi tersebut dapat disimpulkan bahwa arsip merupakan suatu kumpulan dokumen yang disusun dan disimpan secara teratur di dalam lemari box arsip agar sertiap kali dibutuhkan dapat ditemukan kembali dengan cepat dan mudah.

Pengertian Sistem manajemen kearsipan menurut Laksmi (2008) bahwa Sistem manajemen kearsipan adalah Pelaksanaan pengawasan sistematik dan ilmiah terhadap semua informasi yang terekan yang dibutuhkan oleh sebuah organisasi untuk mendukung tugas-tugas atau kegiatan-kegiatan di dalam organisasi agar tercapai efektifitas maupun efisien.

Menurut Sedarmayanti (2001) yaitu dengn menggunakan bahasa yang praktis yang dapat di mengerti artinya oleh penulis surat, maupun menggunakan surat dan kata yang di pergunakan adalah kata yang sederhana, umum dan bukan bahasa daerah atau bahasa asing. Di samping harus mempergunakan bahasa praktif, karena keberhasilan suatu surat juga di pengaruhi oleh gaya bahasa. Dalam surat menyurat gaya bahasa sangat di pergunakan oleh dua faktor yaitu kedudukan penulis surat terhadap yang di kirim surat dan persoalan yang di kemukakan dalam isi surat. 
Sedangkan menurut Sugiarto (2005) bahwa Sistem Manajemen Kearsipan merupakan salah satu bagian dari Manajemen Perkantoran yang hakekatnya pada pengurusan dokumen sedemikian rupa agar dokumendokumen yang dikelola dan para petugas kearsipan harus benar-benar akan membantu serta mendukung aktivitas manajemen secara keseluruhan.

Dari pengertian diatas dapat disimpulkan bahwa Manajemen kearsipan merupakan suatu gabungan antara seni dan ilmu yang mengatur tentang kearsipan mulai dari penyimpanan hingga penyusutan yang disusun secara teratur agar dapat ditemukan kembali dengan cepat dan baik.

Ketiga arsip harus dapat di temukan kembali secara fisik maupun informasinya, arsip dapat di bedahkan dengan non arsip, karena non arsip merupakan keseluruhan informasi dalam bentuk yang tidak nyata seperti percakapan biasa, namun non arsip akan bisa menjadi arsip. Hal ini yang di kemukakan oleh Milburn D. Smith ill.

Pengertian nilai guna arsip menurut sedarmayanti (2003) adalah suatu proses penilaian arsip untuk menentukan jangka waktu penyimpanan atau retensi arsip yang di dasarkan atas pengkajian terhadap isi arsip, yang penataannya berhubungan dengan arsiparsip lainnya.

\section{METODE}

Metode Kualitatif merupakan Metode Penelitian Naturalistik karena penelitiannya dilakukan pada kondisi yang alamiah karena data atau dokumen yang terkumpul dan analisisnya lebih bersifat kualitatif. Analisis data yang dilakukan bersifat induktif berdasarkan fakta-fakta yang ditemukan di lapangan dan kemudian dikonstruksikan menjadi hipotesis atau teori.

Metode tersebut dimaksudkan untuk mempelajari dan meneliti bagaimana cara pengelolaan terhadap kearsipan sehingga dapat menambah pemahaman Aparatur Sipil Negara terhadap pelaksanaan pengelolaan kearsipan yang baik.

Lokasi Penelitian berada di Sekolah Usaha Perikanan Menengah Sorong yang beralamat di Jalan Jenderal Ahmat Yani No.32 Kelurahan Klakublik Kota Sorong Provinsi Papua Barat.

Jenis dan sumber data terdiri dari data primer dan data sekunder :

- Data Primer adalah data yang di peroleh langsung dari lapangan disamping dokumen tertulis, biasanya didapatkan dari subjek penelitian dengan cara melakukan pengamatan, percobaan atau wawancara langsung dengan responden.

- Data Sekunder adalah data yang tidak langsung diperoleh dari sumber pertama, dan telah tersusun dalam bentuk dokumen tertulis. data-data yang digunakan adalah melalui buku-buku referensi serta Peraturan Perundang-Undangan yang ada relevansinya dengan objek yang akan di bahas, data sekunder ini akan diperoleh dengan berpedoman pada literatur-literatur sehingga dinamakan penelitian kepustakaan.

Penelitian Kepustakaan adalah penelitian yang dilakukan dengan mempelajari bahan-bahan hukum yang berkaitan dengan data sekunder yang terdiri dari: 1. Undang-Undang Dasar Tahun 1945

2. Undang-Undang Nomor 5 Tahun 2014 tentang Aparatur Sipil Negara (ASN)

3. Undang-Undang Nomor 43 Tahun 2009 tentang Kearsipan

4. Peraturan Menteri Kelautan dan Perikanan

5. Buku-buku Kearsipan

6. Modul-modul Kearsipan

7. Majalah-majalah Kearsipan

\section{HASIL DAN PEMBAHASAN}

Pembahasan ini mengacu pada Undang-Undang Nomor 5 Tahun 2014 tentang Aparatur Sipil Negara, dan Undang-Undang Nomor 43 Tahun 2009 tentang Kearsipan, maka di jelaskan bahwa dalam rangka pelaksanaan cita-cita bangsa dan mewujudkan tujuan negara sebagaimana tercantum dalam pembukaan Undang-Undang Dasar Negara Republik Indonesia Tahun 1945, perlu dibangun aparatur sipil negara yang memiliki integritas, profesional, netral dan bebas dari intervensi politik, bersih dari praktik korupsi, kolusi, dan nepotisme, serta mampu menyelenggarakan pelayanan publik bagi masyarakat dan mampu menjalankan peran sebagai unsur perekat persatuan dan kesatuan bangsa berdasarkan Pancasila dan Undang-Undang Dasar Negara Republik Indonesia Tahun 1945.

Bahwa untuk mewujudkan aparatur sipil negara sebagai bagian dari reformasi birokrasi, perlu ditetapkan aparatur sipil negara sebagai profesi yang memiliki kewajiban yang mengelola dan mengembangakan dirinya dan wajib mempertanggung jawabkan kinerjanya dan menerapkan prinsip merit dalam pelaksanaan manajemen aparatur sipil negara.

Sedangkan di dalam undang-undang nomor 43 tahun 2009 tentang pengertian kearsipan dan arsip sudah sangat jelas, tinggal bagaimana penerapannya dalam pengelolaan arsip bagi kehidupan kebangsaan, 
organiasi, perusahaan dan perkantoran sehingga pada akhirnya dapat terwujud dunia kearsipan tanah air yang terkelola secara optimal, efektif dan efisien.

Arsip adalah rekaman kegiatan atau peristiwa dalam berbagai bentuk dan media sesuai dengan perkembangan teknologo informasi dan komunikasi yang dibuat dan diterima oleh lembaga negara, pemerintah daerah, lembaga pendidikan, perusahaan, organisasi politik, organisasi kemasyarakatan dan perseorangan dalam pelaksanaan kehidupan bermasyarakat, berbangsa dan bernegara.

Tahap terciptanya arsip awal dari lahirnya suatu ide dan gagasan untuk selanjutnya di cantumkan dalam bentuk isi naskah atau surat, yang disebut dengan konsep dengan tulisan tangan kemudian diolah dengan kata-kata dan kalimat sehingga terbentuk menjadi surat, formulir dan laporan dan sebagai proses dalam terciptanya arsip yang disebut dengan manajemen surat menyurat.

Surat secara umum dapat juga disebut sebagai alat untuk menyampaiakan suatu maksud secara tertulis, karena banyak persoalan yang memerluhkan bukti tertulis, karena surat memiliki bukti autentik berupa tulisan dan tanda tangan yang tidak dapat dimiliki oleh alat komunikasi lisan, apalagi yang berhubungan dengan aspek hukum, sudah tentu pasti memerlukan bukti tertulis hitam di atas putih.

Untuk menghasilkan surat yang baik, harus objektif dan bukan subjektif, isi surat haru rapi, jelas, singkat dan tidak bertele-tele serta wujud fisik surat yang menarik, agar menghasilkan surat yang baik, benar dan surat yang memenuhi syarat. lain :

Surat dapat juga ditinjau dari beberapa segi antara

- Menurut wujudnya yaitu kartu pos, surat bersampul, memorandum dan nota, telegram dan surat pengantar

- Menurut tujuannya yaitu surat pemberitahuan, surat perintah, surat permintaan, surat peringatan, surat panggilan, laporan, surat perjanjian dan surat keputusan

- Menurut sifat isinya yaitu surat dinas, surat pribadi dan surat niaga

- Menurut jumlah penerima yaitu surat biasa, surat edaran dan surat pengumuman

- Menurut keamanan isinya yaitu surat rahasia, surat sangat rahasia dan surat biasa

- Menurut prosedur pengurusannya yaitu surat masuk dan surat keluar
- Menurut jangkauan yaitu surat interen dan surat eksteren.

Bahwa Pelaksanaan manajemen aparatur sipil negara belum berdasarkan pada perbandingan antara kompetensi dan kualifikasi yang diperluhkan oleh jabatan dengan kompetensi dan kualifikasi yang dimiliki calon dalam rekrutmen, pengangkatan, penempatan dan promosi pada jabatan sejalan dengan tata kelola pemerintahan yang baik.

Aparatur Sipil Negara pada Sekolah Usaha Perikanan Menengah Sorong pada dasarnya telah menjalankan tugas dan fungsinya sebagai abdi negara dan pelayanan publik, terutama pada unit-unit yang menangani surat menyurat yang akan nantinya menjadi arsip sebagai bukti pada saat audit maupun sebagai bukti pertanggung jawaban dalam pemeriksaan yang berhubungan dengan pelanggaran yang berakibat dengan persoalan hukum, namun pada dasarnya Pegawai di Sekolah Usaha Perikanan Menengah Sorong masih menganggap arsip hanya sekedar selesai pengiriman surat maka selesailah sudah pekerjaan mereka, tapi mereka belum paham tentang surat yang akan di kirim itu nantinya akan menjadi bukti sejarah bagi Masyarakat, Bangsa dan Negara Republik Indonesia.

Untuk di ketahui bahwa pada suatu instansi pemerintah tidaklah mudah dalam penanganan arsip, pasti ada saja kendalah yang mengakibatkan fatal karena tercecer dan hilangnya suatu arsip atau dokumen penting bagi kelancaran kegiatan, oleh sebab itu perlu di terapkan sebuah sistem pengelolaan arsip yang baik pada pegawai di Sekolah Usaha Perikanan Menengah Sorong ysng di sebut dengan Sitem Manajemen Kearsipan.

Pengendalian arsip merupakan surat masuk dan surat keluar di catat sesuai dengan sistem yang telah ditentukan, setelah itu surat-surat di arahkan atau dikendalikan untuk di proses lebih lanjut. Proses surat dapat di lakukan dengan menggunakan buku agenda surat masuk atau keluar. Penanganan sistem surat masuk dan surat keluar berisi kolom-kolom untuk mencatat surat masuk dan surat keluar serta untuk mengendalikan.

\begin{tabular}{|l|l|l|l|l|l|}
\hline $\begin{array}{l}\text { No } \\
\text { urut }\end{array}$ & $\begin{array}{l}\text { No } \\
\text { surat }\end{array}$ & $\begin{array}{l}\text { Tgl } \\
\text { srt msk }\end{array}$ & $\begin{array}{l}\text { Hal } \\
\text { srt }\end{array}$ & $\begin{array}{l}\text { Asal } \\
\text { srt }\end{array}$ & $\begin{array}{l}\text { Kode } \\
\text { arsip }\end{array}$ \\
\hline & & & & & \\
\hline & & & & & \\
\hline & & & & & \\
\hline
\end{tabular}

Gambar 1. Buku Agenda Surat Masuk Sumber dari : Tata Usaha SUPM Sorong 


\begin{tabular}{|l|l|l|l|l|l|}
\hline $\begin{array}{l}\text { No } \\
\text { urut }\end{array}$ & $\begin{array}{l}\text { Kode } \\
\text { srt }\end{array}$ & $\begin{array}{l}\text { No } \\
\text { srt }\end{array}$ & $\begin{array}{l}\text { Tgl } \\
\text { srt }\end{array}$ & $\begin{array}{l}\text { Hal } \\
\text { srt }\end{array}$ & $\begin{array}{l}\text { Kepada/ } \\
\text { tujuan }\end{array}$ \\
\hline & & & & & \\
\hline & & & & & \\
\hline & & & & & \\
\hline
\end{tabular}

Gambar 1. Buku Agenda Surat Keluar Sumber dari : Tata Usaha SUPM Sorong

Dapat di ketahui surat atau arsip yang ditangani dan merupakan langkah-langkah mempermudah jalannya surat tanpa harus membuat suatu kesalahan dalam membuang waktu untuk pencarian arsip.

Agenda adalah pencatatan surat keluar dan surat masuk dapat dipisahkan dengan menggunakan buku agenda surat masuk dan buku agenda surat keluar.

Pengelola surat maupun arsip pada Unit Pelaksana Teknis Sekolah Usaha Perikanan Menengah Sorong, berpedoman pada Peraturan Menteri Kelautan dan Perikanan Republik Indonesia Nomor 52/PERMENKP/2014 tentan Pedoman Umum Tata Naskah Dinas di Lingkungan Kementerian Kelautan dan Perikanan. sedangkan Pemberkasan arsip dan penyusutan arsip berpedoman pada Pearturan Menteri Kelautan dan Perikanan Republik Indonesia Nomor 53/PERMEN$\mathrm{KP} / 2014$ tentang Sistem Pemberkasan Arsip, dan Nomor 50/PERMEN-KP/2014 tentang Penyusutan Arsip di Lingkungan Kementerian Kelautan dan Perikanan.

Sistem kode klasifikasi mengacu pada Tata Naskah Dinas di Lingkungan Kementerian Kelautan dan Perikanan yakni:

- Pengelompokan surat atau arsip berdasarkan pada kode klasifikasi surat.

- Pengelompokan atau pemilahan jenis surat atau arsip

- Penguruta secara numerik berdasarkan pada pencatatan di buku agenda surat masuk dan buku agenda surat keluar

- Pencatatan dan pemindaian/scan di komputer untuk mempermudah pencairan/penelusuran kembali arsip, pemindaian hanya dilakukan pada arsip-arsip yang penting atau vital atau arsip yang memiliki frekuensi penggunaan yang sangat tinggi.

- Penataan arsip di odner/bindex pada lemari arsip

- Penataan arsip di odner/bindex sesuai kode klasifikasi dan urutan nomor pencatatan agenda surat masuk dan surat keluar.

Penanganan surat masuk dan surat keluar, setiap surat masuk yang diterima dan surat keluar yang di kirim oleh suatu organisasi pemerintah maupun swasta mempunyai nilai yang sangat penting, baik sebagai alat komunikasi, sebagai informasi pelayanan publik, sebagai pusat ingatan, seabagai bukti outentik dan sekaligus dapat menunjukkan dinamika organisasi. Pengurusan surat dengan menggunakan buku agenda yang merupakan suatu proses pencatatan surat mausk atau surat keluar dengan menggunakan buku agenda dan buku ekspedisi interen atau eksteren.

Menurut fungsi dan kegunaannya arsip terdiri dari arsip dinamis, aktif, inaktif, vital, statis, terjaga dan arsip umum adalah sebagai berikut :

1. Arsip dinamis adalah arsip yang digunakan secara langsung dalam kegiatan pencipta arsip dan disimpan selama jangka waktu tertentu.

2. Arsif aktif adalah Arsip yang frekuensi penggunaannya tinggi dan atau terus menerus

3. Arsip inaktif adalah arsip yang frekuensi penggunaannya telah menurun atau berkuran.

4. Arsip vital adalah arsip yang keberadaannya merupakan persyaratan dasar bagi kelangsungan operasional pencipta arsip, tidak dapat di perbaharui, dan tidak dapat tergantikan apabila rusak atau hilang

5. Arsip statis adalah arsip yang di hasilkan oleh pencipta arsip karena memiliki nilai guna kesejarahan, dan telah habis retensinya, sehingga keterangan di permanenkan, yang telah di verifikasi baik secara langsung maupun tidak langsung oleh Arsip Nasional Republik Indonesia dan/atau lembaga kearsipan.

6. Arsip terjaga adalah arsip negara yang berkaitan dengan keberadaan dan kelangsungan hidup bangsa dan negara yang harus di jaga keutuhan, keamanan dan keselamatannya

7. Arsip umum adalah arsip yang tidak termasuk dalam kategori arsip terjaga.

Manajemen asip pada setiap kegiatan bantuan data dan informasi, demikian juga pada kegiatan pengambilan keputusan juga dari bantuan data dan informasi yang benar dan dapat dihasilkan secara efektif dan efisien.

Manajemen adalah para pemimpin yang bertugas membuat keputusan yang berkaitan dengan perencanaan, pelaksanaan, dan pengawasan dari masing-masing fungsi yang ada di perkantoran, baik pada tingkat manajemen menengah maupun manajemen bawah.

Dua pengertian di atas masing-masing dapat di jelaskan untuk kegiatan kearsipan adalah sebagai berikut, suatu rangkaian metode yang telah menjadi pola tetap dalam melakukan suatu pekerjaan yang merupakan suatu kebulatan seabagai prosedur penyimpanan arsip. 
Pengelolaan kearsipan adalah rangkaian kegiatan mengelola seluruh unsur yang digunakan atau terlibat di dalam proses pengurusan arsip, dan usaha pengelola kearsipan di lakukan melalui pelaksanaan fungsi-fungsi perencanaan, pengorganisasian, penyusunan personalia, pengarahan dan pengendalian atau pengawasan terhadap arsip dan sumber daya yang ada untuk pengurusan kearsipan.

Pelaksanaan manajemen dalam suatu organisasi bertujuan untuk mewujudkan efektifitas dan efesien kerja dalam mencapai tujuan dan hasil dari pelaksanan serangkaian kegiatan.

Dalam kegiatan tersebut terdapat suatu rangkaian ketentuan-ketentuan mengenai cara penyimpanan arsip antara lain meliputi : memisah-misah (segregating), meneliti (examining), memadukan (assembling), mengklasifikasi (classification), mengindeks (indexing), mempersiapkan tunjuk silang (cross reference) serta menyusun dan memfile.

Kearsipan sebagai kelompok ilmu pengetahuan tertentu yang mempelajari tentang hal ihwal arsip dari perorangan, badan swasta atau organisasi pemerintah yang sangat penting untuk keperluan penelitian atau sumber ingatan di kemudian hari.

Setiap kegiatan tersebut, baik dalam organisasi, pemerintah atau swasta selalu ada kaitannya dengan masalah arsip. Oleh karena itu untuk menyajikan informasi yang benar, lengkap dan cepat, maka haruslah ada manajemen dan prosedur kerja yang baik di dalam mengelola kearsipan sehingga arsip dapat menjadi pedoman bagi kelancaran pekerjaan.

Namun pada dasarnya pegawai di Sekolah Usaha Perikanan Menengah Sorong pada umumnya masih tidak berfikir bahwa arsip itu penting, sehingga banyak arsip yang ada di unit-unit mereka yang belum dapat di kelolah dengan baik dan benar sehingga kalau ada yang membutuhkan arsip baik itu arsip negara maupun arsip untuk pengurusan masalah pribadi seperti kenaikan pangkat dll masih sulit di temukan karena pada tercecer di mana-mana dan tidak tahu arsip atau berkas ada di mana. Itu adalah suatu kelemahan pegawai dalam menegelola arsip pada Sekolah Usaha Perikanan Menengah Sorong.

Dengan kata lain setiap organisasi pasti memerlukan suatu unit yang mengelola segala sesuatu yang berhubungan dengan kegiatan administrasi, kegiatan administrasi merupakan kegiatan yang cakupannya luas, dan biasanya segala kegiatan administrasi diolah suatu unit tersendiri yang disebut dengan bagian administrasi, tata usaha, sekretariat kantor, urusan umum dll.

Kegiatan administrasi di suatu kantor pada dasarnya juga mempunyai suatu hasil seperti unitunit lain. Yang dimaksud dengan hasil atau produk dari suatu kantor adalah surat, dokumen, formulir dan laporan, pengelolaan surat, dokumen, formulir dan laporan yang dihasilkan dan yang diterima dari suatu kantor pada akhirnya akan berhubungan dengan kearsipan, sehingga yang disebut dengan kegiatan administrasi pada dasarnya adalah menghasilkan, menerima, mengolah dan menyimpan berbagai surat, dokumen, formulir, laporan dll. Salah satu sumber data adalah arsip, karena arsip adalah bukti dan rekaman dari kegiatan terdepan sampai kepada kegiatan pengambilan keputusan.

Adapun hambatan yang yang membuat arsip tertumpuk dan tidak tertatah dengan baik pada tempatnya di karenakan kurangnya ilmu pengetahuan dalam menata arsip, yang terdapat pada Sekolah Usaha Perikanan Menengah Sorong, Aparatur Sipil Negara di unit-unit kerja masing-masing seperti di ruangan Tata Usaha, Kepegawaian, Keuangan, Kesiswaan, Pengajaran, Kehumasan dan Sarana Pendidikan pada dasarnya masi belum sempurnah dalam menangani arsip di unit-unit tesebut, dikarenakan Aparatur Sipil Negara belum atau kurang memiliki ilmu pengetahuan dan keterampilan di bidang kearsipan, karena mereka anggap itu bukan pekerjaan pokok atau tugas pokok sehingga arsip yang ada di unit-unit tersebut belum efektif dalam pengelolaannya.

Pada hal kalau mau dikatakan yang namanya Aparatur Sipil Negara yang bekerja pada instansi pemerintah yang berhubungan dengan bagian administrasi perkantoran itu sudah jelas bahwa dia seharusnya sudah siap dalam melaksanakan tugas atau amanah negara yang diimbani, walaupun itu diluar tugas pokok dan fungsi. Karena kalau berurusan dengan administrasi, maka sudalah tentu berurusan juga dengan kearsipan dan arsip.

Yang kita ketahui arsip merupakan salah satu hal yang sangat penting dan fundamental sehingga pertanggung jawaban dalam pengelolaan birokrasi baik pemerintah maupun pendidikan. Walaupun banyak permasalahan yang terjadi hanya diakibatkan oleh salah urus sistem penyimpanan arsip pada setiap organisasi atau sistem birokrasi pemerintah.

Dalam pelaksanaan kegiatan kantor yang semakin berkembang, maka semakin banyak dokumen dan data-data maupun arsip yang terkumpul dan disimpan karena masih mempunyai nilai guna, sehingga perlu penyimpanan secara sistematis sehingga apabila 
dibutuhkan dapat diketemukan dengan mudah dan cepat. karena arsip sangatlah penting dalam perjalanan kehidupan sebuah instansi perkantoran, oleh karena itu untuk menjaga kehidupan arsip mulai dari tahap penciptaan, penggunaan, pemeliharaan dan pemindahan serta pemusnahan, maka diperluhkan sistem yang baik dan agar dapat diproses lebih baik pula.

Arsip yang ada pada suatu lembaga pemerintah atau swasta dan lebih terkhusus pada Sekolah Usaha Perikanan Menengah Sorong merupakan bahan resmi dari suatu perencanaan, pelaksanaan, penyelenggaraan kehidupan instansi pendidikan, juga berfungsi menyediakan bahan bukti untuk pertanggung jawaban kegiatan organisasi yang bersangkutan. Dengan demikian arsip diperlukan untuk keperluan pengambilan keputusan atau kebijakan baru oleh pimpinan intsansi atau perusahaan yang memerlukan data kearsipan. Karena kearsipan memegang peranan bagi kelancaran jalannya organisasi yaitu sebagai sumber informasi pelayanan publik dan sebagai pusat ingatan bagi organisasi, oleh karena itu perlu dilakukan dengan prosedur yang baik dan benar di dalam pengelolaan arsip pada unit pelaksana teknis Sekolah Usaha Perikanan Menengah Sorong.

Di samping pengertian pengelolaan dan sistem manajemen arsip, maka perlu difahami tentang daur hidup kearsipan, dalam daur hidup kearsipan terdiri dari beberapa tahap-tahapan dalam proses kehidupan arsip. Dan untuk menjaga daur hidup arsip harus berawal dari tahapan penciptaan, penggunaan, pemeliharaan dan pemindahan serta pemusnahannya, dalam pekerjaan penyimpanan arsip tidak hanya menyimpan saja, akan tetapi menyangkut penempatan dan penemuan kembali. penyimpanan arsip dikatakan baik apabila pada waktu diperluhkan dapat ditemukan kembali dengan mudah, cepat dan tepat.

Kalau berbicara tentang arsip, maka haru didukung juga dengan tempat atau ruangan penyimpanan arsip atau dokumen negara dalam suatu kantor pemerintahan, kalau kita hanya berbicara tentang arsip tapi tidak disertai dengan tempat atau ruangan arsip, maka pastilah arsip itu akan tetap menumpuk pada tempat dimana kita bekerja bisa di samping meja, diatas meja maupun di bawah meja. Itu juga yang terjadi di Sekolah Usaha Perikanan Menengah Sorong, karena berhubungan dengan tidak adanya anggaran untuk operasional ruangan kearsipan, sehingga belum efektif juga terhadap pengelolaan dan penyimpanan arsip pada tempatnya.
Hal tersebut juga bisa dikatakan sebagai hambatan dalam pelaksanaan sistem dalam pengelolaan kearsipan yang tidak efektif dan efisien. Dan apabila sampai tidak ada pengawasan terhadap pelaksanaan kearsipan, khususnya pelaksanaan penyimpanan berkas atau dokumen yang disebut dengan arsip aktif dan arsip inaktif.

Karena pada hakekatnya kalau di suatu instansi pemerintah atau swasta pasti ada yang namanya arsip, dan arsip pun harus memiliki tempat penyimpanan yang di namakan dengan ruangan arsip. Karena tidak adanya ruangan arsip di Sekolah Usaha Perikanan Menengah Sorong, maka inilah salah satu yang membuat tumpukan arsip di beberapa unit ruangan belum tertatah dengan baik dan benar.

Pada hal untuk instansi pemerintah menurut saya seharusnya ada yang namanya ruangan perpustakaan dan ruangan kearsipa, karena ruangan arsip itu untuk penyimpanan arsip inaktif sedangkan arsip yang aktif dalam arti kita masih sering menggunakan untuk kegiatan kantor itulah yang berada di sekitar kita atau di dekat meja kita karena masih dapat di olah lagi.

Kalau berbicara dengan arsip atau ruangan arsip pasti juga ada yang namanya alat penyimpanan arsip, alat penyimpanan arsip terdidiri dari :

- Filling Cabinert adalah tempat untuk penyimpanan arsip dinamis aktif di dalamnya ada susunan sekat dan folder secara vertikal dalam laci-lacinya, dimana penyusunannya mulai dari atas kebawah. - Folder adalah map sebagai tempat penyimpanan arsip sehingga arsip dapat terhimpun dalam suatu wadah baik secara seri, rubrik maupun dosier, pada folder terdapat tab yang menonjol dan fungsinya untuk mencantumkan titel dan kode klasifikasi.

- Rak adalah tempat penyimpanan arsip yang terbuka, penggunaan rak lebih muda di bandingkan menggunakan filling cabinet karena tidak perlu membuka laci sebagaimana membuka filling cabinet.

- Guide atau sekat adalah alat yang digunakan sebagai batas atau petunjuk antara pokok masalah (primer) dengan rinciannya (sekunder dan tertier). - Lemari adalah tempat penyimpanan yang di dalamnya menggunakan bindex-bindex agar terlihat rapi dalam penataan arsipnya

- Bindex adalah tempat untuk menaruh surat dan dokumen yang telah di bolong tepihnya untuk di simpan di lemari atau rak dll.

Dalam penyimpanan arsip haru memperhatikan langkah-langkah sebagai beriku : 
- Memeriksa, agar arsip atau dokumen yang selalu terkontrol keberadaannya, dan untuk mengetahui pola arsip atau dokumen.

- Mengindeks, agar menyatuhkan atau mengelompokan arsip atau dokumen dengan menggunakan kode.

- Memberi tanda atau kode, agar arsip atau dokumen untuk memudahkan penyimpanan dan mudah di temukan kembali pada saat diperluhkan.

- Menyortir, agar mengelompokan kembali arsip atau dokumen untuk di simpan atau agar di musnahkan.

- Penyimpanan, agar arsip atau dokumen dapat terjaga dan aman pada tempatnya dan tidak bertumpuk di kiri dan kanan menja kerja dll.

Penemuan kembali, arsip diawali dengan adanya permintaan dari pengguna, sehingga antara peminjaman dan penemuan kembali arsip merupakan suatu hal yang berkaitan dengan ketepatan dan kecepatan dalam menemukan atau mendapatkan arsip. untuk peminjaman arsip akan sangat bergantung dari beberapa hal sebagai berikut:

- Kejelasan materi yang dimintah oleh pengguna

- Ketepatan sistem pemberkasan yang digunakan dalam pemberkasan jenis-jenis arsip

- Ketepatan dan kemantapan sistem indeks

- Ketepatan dan kemantapan sistem kode klasifikasi

Tersediannya tenaga arsiparis yang memiliki pengetahuan dan keterampilan yang tugasnya untuk menangani kearsipan.

Untuk tenaga arsiparis pada Unit Pelaksana Teknis Sekolah Usaha Perikanan Menengah Sorong telah mempunyai 1 (satu) orang tenaga arsiparis, yang selama ini sudah menjalankan tugas sebagaimana mestinya, namun masih ada saja kendalah dalam penanganan arsip pada Sekolah Usaha Perikanan Menengah Sorong, karena keterbatasan ruangan arsip dan tidak ada rak arsip, sehingga arsip yang ada belum terlaksana dengan baik dan benar, di karenakan tidak didukung dengan anggaran atau operasional kearsipan sehingga pengelolaan arsip belum dikatakan efektif dan efisien pada Sekolah Usaha Perikanan Menengah Sorong.

Kegiatan kearsipan pada dasarnya tidak hanya saat penyimpanan saja, akan tetapi sudah di mulai sejak arsip tersebut di ciptakan, di proses, di simpan sampai akhirnya arsip tersebut di musnahkan, yang di namakan dengan pemeliharaan atau perawatan arsip, ini juga yang terdapat pada Sekolah Usaha Perikanan Menengah Sorong.

Siklus hidup arsip di mulai dari kegiatan penciptaan arsip yaitu penulisan surat, memo, formulir, laporan gambar, hal ini juga di sebut sebagai korespondensi manajemen pengelolaan kearsipan.

Terkait dengan proses penciptaan arsip atau pembuatan arsip bahwa pada dasarnya arsip yang tercipta sering dengan pelaksanaan Tugas Pokok dan Fungsi masing-masing unit kerja Aparatur Sipil Negara pada Sekolah Usaha Perikanan Menengah Sorong. Arsip tercipta sebagai tindak lanjut surat masuk dan surat keluar yang diterima oleh lembaga kantor yang selanjutnya di terima oleh unit kerja terkait untuk di proses lebih lanjut. Yang dimaksud dengan unit kerja adalah bagian-bagian yang mengolah surat masuk dan surat keluar yang nanti akan menjadi arsip yang ada di Sekolah Usaha Perikanan Menengah Sorong yaitu unit kerja bagian Tata Usaha, Kepegawaian, Keuangan, Pengajaran, Kesiswaan, Hubungan Masyarakat (HUMAS) dan Sara Prasarana Pendidikan (SARDIK), dan selanjutnya arsip dapat di kelola oleh masing-masing unit keja tersebut dalam bentuk arsip surat keluar dan arsip surat masuk, sehingga arsip disebut sebagai arsip aktif dan arsip inaktif serta arsip statis.

Demikian pula langkah-langkah penataan arsip aktif surat masuk dan surat keluar, untuk arsip-arsip hasil dari unit kerja lain dikelola dengan memperhatikan prinsip asal usul arsip, arsip di kelompokan berdasarkan unit kerja pencipta, yang di kelompokan berdasarkan subjek atau kode klasifikasi, pengurutan secara numerik nomor pencatatan, dan dicatat di komputer. Arsip-arsip vital dikelola dengan sistem subjek, di kelompokan berdasarkan jenis atau permasalahan arsip.

Pada dasarnya pengelolaan arsip menganut sistem disentralisasi, arsip-arsip di simpan atau dikelola masing-masing unit kerja pengola. Namun demikian ketika arsip menjadi inaktif untuk dikelola di bagian pengelola kearsipan sebagai pusat arsip di Sekolah Usaha Perikanan Menengah Sorong. hal dimaksud untuk menjaga keberadaan ruang arsip di masing-masing unit kerja juga untuk menjamin terselamatnya arsip yang kemungkinan bernilai guna sejarah, pembuktian ataupun penelitian di masa yang akan datang.

Penggunaan arsip ini dapat melalui dua cara yaitu dengan cara meminjam dan dengan cara meminta atau arsip di fotocopy. Dalam layanan peminjaman arsip, terdapat Standar Operasional Prosedur (SOP) yakni

- Pengguna formulir peminjaman arsip

- Persetujuan/disposisi kepada bagian kearsipan

- Penelusuran arsip oleh arsiparis, melalui aplikasi SIKAP atau manual 
- Penyerahan Arsip, bagi peminjam arsip di wajibkan mengisi formulir peminjaman terlebih dahulu

- Penyerahan fotocopy arsip

Di Bagian Tata Usaha Sekolah Usaha Perikanan Menengah Sorong mempunyai tugas pokok adalah melakukan urusan persuratan dan kearsipan, serta melakukan penyimpanan surat dan dokumendokumen di bidang ketata Usahaan, hubungan masyarakat, organiasi, perlengkapan, hukum dan keuangan. Jadi bagian tata usaha selain memiliki tugas menciptakan arsip juga mempunyai tanggung jawab menyimpan segala arsip yang berhubungan dengan lingkungan Pendidikan.

Peran tanggung jawab ini tentunya sudah di bedahkan dengan unit-unit lain, seperti di keuangan, kepegawaian, pengajaran, kesiswaan, kehumasan dan sarana prasarana pendidikan, bagian tata usaha menciptakaan arsip dan penyimpanan arsip berbeda dengan yang di simpan di unit perpustakaan.

Keberadaan tempat penyimpanan arsip yang ada di Unit Tata Usaha Sekolah Usaha Perikanan Menengah Sorong yang relatif sempit dan kemungkinan akan menimbulkan masalah di kemudian harinya, karena setiap hari arsip bertambah dan tentunya juga harus membutuhkan tambahan ruangan untuk penyimpanan arsip, apalagi di Sekolah Usaha Perikanan Menengah Sorong belum pernah melakukan penyusutan arsip.

Apalagi tenaga arsiparis yang ada di unit Pelaksana Teknis Sekolah Usaha Perikanan Menengah Sorong hanya 1 (satu) orang tentunya sangat kurang, karena volume pekerjaannya saling terikat satu sama yang lainnya, sehingga untuk penyusutan arsip belum dapat di laksanakan.

Nilai guna arsip di dasarkan pada kegunaannya bagi kepentingan pengguna arsip. Nilai guna arsip dapat di bedahkan menjadi :

1. Nilai guna primer meliputi nilai guna administrasi, keuangan, hukum, teknologi dan ilmiah

2. Nilai guna sekunder

3. Nilai guna kebutuhan

4. Nilai guna informasi

Pedoman umum untuk menentukan nilai guna arsip, dapat di ketahui bahwa penentuan nilai guna arsip merupakan kegiatan untuk memisahkan arsiparsip ke dalam dua kategori yaitu arsip yang bernilai guna permanen yang terus di simpan, sedangkan arsip yang bernilai guna sementara yang dapat di musnahkan dengan segera atau di kemudian hari.
Keberhasilan dari penilaian tersebut tergantung kepada :

1. Kemantapan pengertian dan pemahaman terhadap cara dan bagaimana kegiatan instansi itu terekam dalam arsip

2. Pengertian dan kesadaran akan fungsi kegunaan arsip bagi penggunaannya serta kepentingan penyelamatan arsip sebagai bahan bukti dan bahan pertanggung jawaban.

Kegiatan tersebut penting untuk menetukan jadwal penyimpanan atau retensi arsip yang menjadi dasar pelaksanaan penyusutan arsip, sebab nilai guna arsip dapat berubah sesuai dengan kepentingan penggunaan dan fungsinya.

Dalam menciptakan suatu sistem penataan arsip yang baik, hendaknya di perhatikan atau di penuhi beberapa faktor penunjang antara lain :

- Kesederhanaan adalah sistem penataan arsip yang di pilih dan di terapkan harus mudah, supaya tidak hanya di mengerti oleh satu orang, namun dapat pula di mengerti oleh orang lain

- Ketepatan penyimpanan arsip adalah berdasarkan sistem yang digunakan harus memungkinkan penemuan kembali arsip dengan cepat dan tepat - Memenuhi persyaratan ekonomis adalah untuk dapat memanfaatkan ruangan, tempat dan peralatan yang ada, serta biaya yang tersedia

- Menjamin keamanan adalah arsip harus terhindar dari kerusakan, pencurian, kemusnahan dan harus aman dari bahaya banjir, air, api dan ganguan binatang lain, sehingga penyimpanan harus di tempat yang benar-benar aman dari segalah gangguan

- Penetapan arsip hendaknya di tempatkan pada tempat yang strategis, maksudnya adalah agar tempat penyimpanan mudah di capai oleh setiap unit yang memerluhkan arsip tersebut tanpa membuang banyak waktu dan tenaga.

- Sistem yang digunakan harus fleksibel adalah harus memberikan kemungkinan adanya perubahan-perubahan dalam rangka penyempurnaan dan ketepatan kerja

- Petugas arsip adalah yang harus memahami pengetahuan di bidang kearsipan

Di dalam penyimpanan arsip harus di perhatikan masalah asas pengorganisasian arsip. arsip dinamis berupa arsip aktif dan arsip inaktif dapat di simpan dan di kelola secara sentralisasi pada suatu unit khusus di dalam organisasi yang biasa di kenal sebagai central file. Sistem penyimpanan arsip secara sentral ini makin efisien dan efektif bila di terapkan pada suatu organisasi yang relatif kecil, rentang 
tugasnya pendek, tidak terlalu kompleks. Beban kerja tidak terlalu besar dan tempat lokasinya tidak terpencar-pencar. Dengan menerapkan asas sentralisasi, maka sistem penyimpanan yang di gunakan akan menjadi standar pengelolaan arsip, seluruh arsip akan dapat di simpan dan di ketemukan kembali dengan aturan dan prosedur yang sama.

Untuk organiasi yang relatif besar, asas penyimpanan yang tepat untuk di terapkan adalah disentralisasi. Dalam asas ini semua unit pengolah di berikan otoritas untuk menyimpan dan mengelola arsip aktifnya, masing-masing asas ini dapat diterapkan apabila organisasi mempunyai rentang tugas yang panjang, beban kerja yang besar dan lokasinya berpencar dan berjauhan. Disamping dua asas ini, organisasi juga dapat menerapkan asas gabungan yang merupakan kombinasi antara asas sentralisasi dan asas desentralisasi.

Prinsip asas ini adalah bahwa setiap unit pengolah di berikan otoritas untuk melakukan penyimpanan dan pengelolaan arsip dengan kontrol atau pengendalian sistem secara terpusat oleh suatu unit, khusus di dalam organisasi. Untuk melakukan penyimpanan arsip-arsip aktif ini ada beberapa yang dapat di terapkan sistem klasifikasi sebagai sistem pemberkasan, dan pemeliharaan sistem pemberkasan yang akan di gunakan sangat bergantung pada kegunaan masing-masing arsip bagi pengguna dan jenis arsip itu sendiri. Sehingga dapat terjadi beberapa arsip yang berbeda di pemberkasan dengan sistem yang berbeda pula.

Di dalam menentukan sistem pemberkasan yang akan di terapkan perlu di pertimbangkan beberapa hal di antaranya adalah bentuk arsip, sifat serta bidang-bidang kegiatan organiasi dan karakteristik organisasi yang bersangkutan. Perlu juga di perhatikan bahwa sistem pemberkasan yang akan di terapkan harus menggambarkan secara jelas bentuk berkas arsipnya, sehingga di dalam penemuan kembalinya dapat di lakukan secara cepat dan tepat.

Suatu arsip dapat menjadi sumber informasi apabila arsip tersebut dapat di temukan kembali fisik dan isi informasinya. Hal ini sesuai dengan konsep dan pengertian yang di kemukakan bahwa unsur arsip agar dapat di katakan sebagai arsip adalah sifatnya yang dapat di ketemukan kembali, fase inilah yang namanya sistem dalam pengelolaan arsip dinamis.

Penemuan kembali di lakukan apabila ada permintaan dari pengguna di sini adalah mereka yang membutuhkan informasi arsip di dalam konteks pelaksanaan kerja atau pelaksanaan fungsi-fungsi manajemen faktor-faktor yang harus di perhatikan di dalam sistem pemberkasan yang diterapkan, sarananya seperti indeks dan tunjuk silang dan juga unsur kecepatan serta ketepatan yang menjadi dasar sistem prosessnya.

Arsip inaktif dalam arti jarang di gunakan, di simpan secara terpusat pada tempat penyimpanan arsip inaktif yang sering di sebut gedung penyimpanan arsip (record center building) atau pusat arsip. Di dalam pusat arsip inaktif seluruh aktifitas yang berkaitan dengan pengelolaan arsip inaktif di lakukan seperti pengolahan penyimpanan, pemeliharaan dan penyusutan serta jasa layanan untuk menjadikan gedung pusat arsip perlu di lakukan perencanaan matang dengan mempertimbangkan aspek ekonomis, efisiensi dan keamanan. Agar pusat arsip arsip ini dapat berfungsi secara maksimal dan dapat melindungi arsip, maka dibutuhkan suatu standar gedung penyimpanan arsip.

Sistem pemeliharaan arsip, upaya untuk memelihara arsip terutama di tujukan untuk melindungi, mengatasi dan mengambil tindakantindakan untuk menyelamatkan fisik terutama informasi arsip. di samping menjamin kelangsungan hidup arsip dari kemusnahan, Pemeliharaan arsip inaktif harus memperhatikan dua faktor pokok yang dapat menyebabkan kerusakan pada fisik arsip, sehingga perlu di lakukan tindakan untuk memelihara, menjaga dan mengamankan terhadap kerusakan kerta secara langsung. Dan faktor eksteren dari lingkungan di mana arsip tersimpan, yang dapat merusak arsip secara tidak langsung.

Bagi manajemen arsip dinamis sendiri, penggunaan komputer memberikan pengaru yang berarti terhadap proses pengolahan penyimpanan, pemeliharaan dan penyajian informasi. Pemanfaatan produk teknologi yang canggih ini menimbulkan dua hal yang sangat signifikan, pertama menimbulkan komputerisasi atau lazim di sebut sebagai otomasi di bidang manajemen kearsipan. Dalam hal ini komputer banyak digunakan sebagai alat atau sarana teknologi untuk kebutuhan administratif, pengolahan, penyimpanan, pengaksesan dan penemuan kembali serta penyajian informsi. Komputerisasi manajemen arsip dinamis, mungkin di terapkan terhadap beberapa sub sistem di antaranya adalah :

- Manajemen formulir elektronik

- Manajemen korespondensi elektronik

- Manajemen surat elektronik

- Sistem penyimpanan arsip aktif elektronik

- Sistem penyimpanan arsip inaktif elektronik

- Sistem penemuan kembali dan penyajian informasi arsip elektronik 
Arsip elektronik ini pada dasarnya juga harus di kelola di dalam suatu sistem yang berdasarkan pada prinsip-prinsip manajemen arsip dinamis.

Arsip memiliki fungsi dan kegunaan yang signifikan di dalam manajemen kegiatan administrasi negara dan pelaksanaan fungsi-fungsi manajemen, karena signifikansi informasinya. Arsip harus dikelola di dalam suatu sistem yang di sebut dengan pengelolaan manajemen arsip dinamis, merupakan pengelolaan terhadap keseluruhan daur hidup arsip.

Dalam hal pengelolaan arsip bagi sebuah instansi pemerintah oleh aparatur sipil negara sudahlah di tentukan dan dijelaskan pada peraturan perundangundangan yang berlaku, dan pegawai di Sekolah Usaha Perikanan Menengah Sorong sampai dengan saat ini pada umumnya sudah fahan tentang arsip melalui ucapan semata, namun pelaksanaannya terhadap kearsipan sangatlah kecil dalam arti secara ucapan iya tapi pelaksanaannya tidak, sehingga penanganan arsip pada masing-masing unit masih di katakan belum efektif terhadap sistem pengelolaan kearsipan yang baik dan benar.

\section{KESIMPULAN}

Di dalam undang-undang Aparatur Sipil Negara dan undang-undang kearsipan yang menjelaskan tentang sistem manajemen kearsipan pada dasarnya sudah sangat jelas penggunaan, penyimpanan, pengelolaan kearsipan maupun arsip. Akan tetapi para Aparatur Sipil Negara sendirilah yang kurang memahami tentang cara penanganan kearsipan dan arsip yang baik dan benar, hal tersebut yang terdapat pada suatu instansi atau unit kerja masing-masing, sehingga arsip yang ada di unit kerja masing-masing terbengkalai dan arsip akan tercecer ke mana-mana. Seperti yang terdapat pada Sekolah Usaha Perikanan Menengah Sorong, karena sampai dengan saat ini arsip masi tertumpuk di bagian-bagian unit kerja masing-masing.

Karena kurangnya pemahaman Aparatur Sipil Negara terhadap penanganan arsip, maka perlu di berikan pelatihan khusus tentang sistem manajemen pengelolan kearsipan, dan pada dasarnya sudah tentu pekerjaan administrasi di suatu unit kerja pemerintah itu dapat berhubungan dengan surat yang nanti akan menjadi arsip yang berguna untuk masa lalu, masa kini dan masa yang akan datang. dengan demikian arsip sebagai alat bukti yang sah.

Keberadaan tempat penyimpanan arsip yang ada di Sekolah Usaha Perikanan Menengah Sorong relatif sempit dan kurang memadai, sehingga inaktif belum dapat di tatah dengan baik dan benar pada tempatnya.
Untuk penanganan arsip yang baik dan benar juga perlu harus adanya ruangan arsip maupun yang mengelola arsip, semua ini juga harus di dukung dengan adanya Sumber Daya Manusia dan Sumber Dana bagi operasional kearsipan. Namum pada hakekatnya semua ini belum efektif di Unit Pelaksana Teknis Sekolah Usaha Perikanan Menengah Sorong.

Sistem manajemen pengelolaan kearsipan pada hakekatnya berhubungan dengan organisasi yang tugasnya untuk menangani arsip, dan kelengkapannya yang meliputi : arsipari, peralatan arsip serta ruangan arsip.

Arsip juga terbagi atas dua arsip aktif dan arsip inakti, arsip aktif yang sewaktu-waktu dapat di perluhkan kembali apa bila di butuhkan, sedangkan arsip inaktif, arsip yang masa retensinya sudah berkurang atau jarang di perlukan dan bisa dapat di musnahkan.

Ada juga arsip elektronik, arsip yang dapat di simpat pada kompiuter yang berupa aplikasi Sistem Informasi Kearsipan (SIKAP) Kementerian Kelautan dan Perikanan. Dan arsip yang dapat di scan dan di simpan pada komputer.

Arsip yang akan di kelola pada Sekolah Usaha Perikanan Menengah Sorong adalah arsip Dinamis yang meliputi arsip aktif dan inaktif.

Sistem manajemen pengelolaan kearsipan sangatlah penting bagi sebuah instansi pemerintah, karena pada dasarnya pekerjaan seorang administrasi adalah mengurus surat dan arsip, karena arsip berperan pesat dalam mendukung pekerjaan suatu organisasi yang dapat di katakan sebagai pedoman dalam membuat sebuah keputusan yang baik dan benar dan sebagai alat bukti yang sah bagi permasalahan hukum.

\section{SARAN}

Dari pembahasan karya ilmiah di atas dapat di pahami bahwa pada hakekatnya masih ada banyak kekurangan dalam penanganan kearsipan dan arsip, maka perlu ada yang namanya Sumber Daya Manusia dan saran prasarana adalah sebagai berikut :

1. Untuk membuat suatu pekerjaan itu baik dan efektif tergantung dari pemahaman dari yang mengelola, dan ingin mendapat pengelola arsip yang handal harus di dasari dengan pelatihan atau diklat arsipari bagi pengelola arsip.

2. Kalau berbicara tentang arsip, maka harus di dukung dengan tempat atau ruangan arsip yang memadai 
3. Berbicara tentang orang yang mengelola arsip, dan ruangan atau tempat arsip, maka perlu juga didukung dengan ekonomis atau dana operasional arsip. dan walaupun Sumber Daya Manusianya ada, dan tempatnya juga ada tapi tidak memadai. sehingga semua yang ada ini perlu yang namanya bantuan dana operasional arsip, agar arsip dapat di proses dengan cepat, baik, dan benar maupun efektif. Karena arsip adalah jatih diri suatu organisasi dan sebagai alat bukti yang sah, yang harus di jaga keamanan, kenyamanan dan kerahasiaannya.

\section{UCAPAN TERIMA KASIH}

Ucapan terima kasih penulis sampaikan kepada Ibu Erni Kristina Pambayuningrum, A.Pi.,M.P selaku Kepala Sekolah Usaha Perikanan Menengah Sorong, yang telah memberi izin kepada penulis dalam pembuatan karya ilmiah ini, sihingga dapat terlaksana dengan baik dan tepat waktu. Ucapan terima kasih penulis sampaikan kepada Bapak Rasman, S.Pi selaku Kepala Sub Bagian Tata Usaha SUPM Sorong, yang telah mengingatkan penulis dalam pembuatan karya ilmiah ini agar cepat selesai pada waktunya. Dan penulis juga ucapkan terima kasih kepada bapak dan ibu Aparatur Sipil Negara yang ada pada Unit Pelaksana Teknis Sekolah Usaha Perikanan Menengah Sorong tanpa terkecuali, yang telah membantu dalam membimbing, memberikan ide, masukan maupun gagasan kepada penulis, sehingga karya ilmiah ini dapat berjalan dengan lancar dan tepat pada waktunya.

\section{DAFTAR PUSTAKA}

Agus Sugiarto dan Teguh Wahyono. 2005, 2013, Manajemen Kearsipan Modern. Yogyakarta: Gava Media.

Choiriyah, 2007. Manajemen Kearsipan. Sukabumi.

Laksmi, dkk. 2008. Manajemen Perkantoran Modern. Jakarta: Penaku
Martono, Boedi. 1994. Peanataan Berkas dalam Manajemen Kearsipan. Jakarta. Sinar Harapan

Priansa, Donni Juni dan Agus Garnida. 2013. Manajemen Perkantoran(Cetakan Kesatu). Bandung: Alfabeta

Sedarmayanti. 2003, 2008, Tata Kearsipan (Cetakan Keempat). Bandung: CV. Mandar Maju.

Suraja, Yohannes. 2006. Manajemen Kearsipan. Malang : Dioma.

Sulistyo Basuki, 2003, Manajemen Arsip Dinamis: Pengantar Memahami dan Mengelolah Informasi dan Dokumen. Jakarta : PT. Gramedia Pustaka Utama,

The Liang Gie.1996. Administrasi Perkantoran Modern (Edisi Ke Empat). Yogyakarta: LIBERTY.

Wursanto, 1991, Kearsipan 1, Yogyakarta : Kanisius Yogyakarta

Peraturan Menteri Kelautan dan Perikanan Nomor : 52/PERMEN-KP/2014 tentang Kearsipan lingkup Kementerian Kelautan dan Perikanan

Peraturan Menteri Kelautan dan Perikanan Nomor : 53/PERMEN-KP/2014 tentang Pedoman Umum Tata Naskah Dinas lingkup Kementerian Kelautan dan Perikanan

Undang-Undang Dasar Negara Republik Indonesia Tahun 1945

Undang-Undang Nomor 5 Tahun 2014 tentang Aparatur Sipil Negara (ASN)

Undang-Undang Nomor 43 Tahun 2009 tentang Kearsipan 
E. PROFIL KEADAAN ARSIP DAN TEMPAT ATAU RUANGAN ARSIP PADA SUPM SORONG
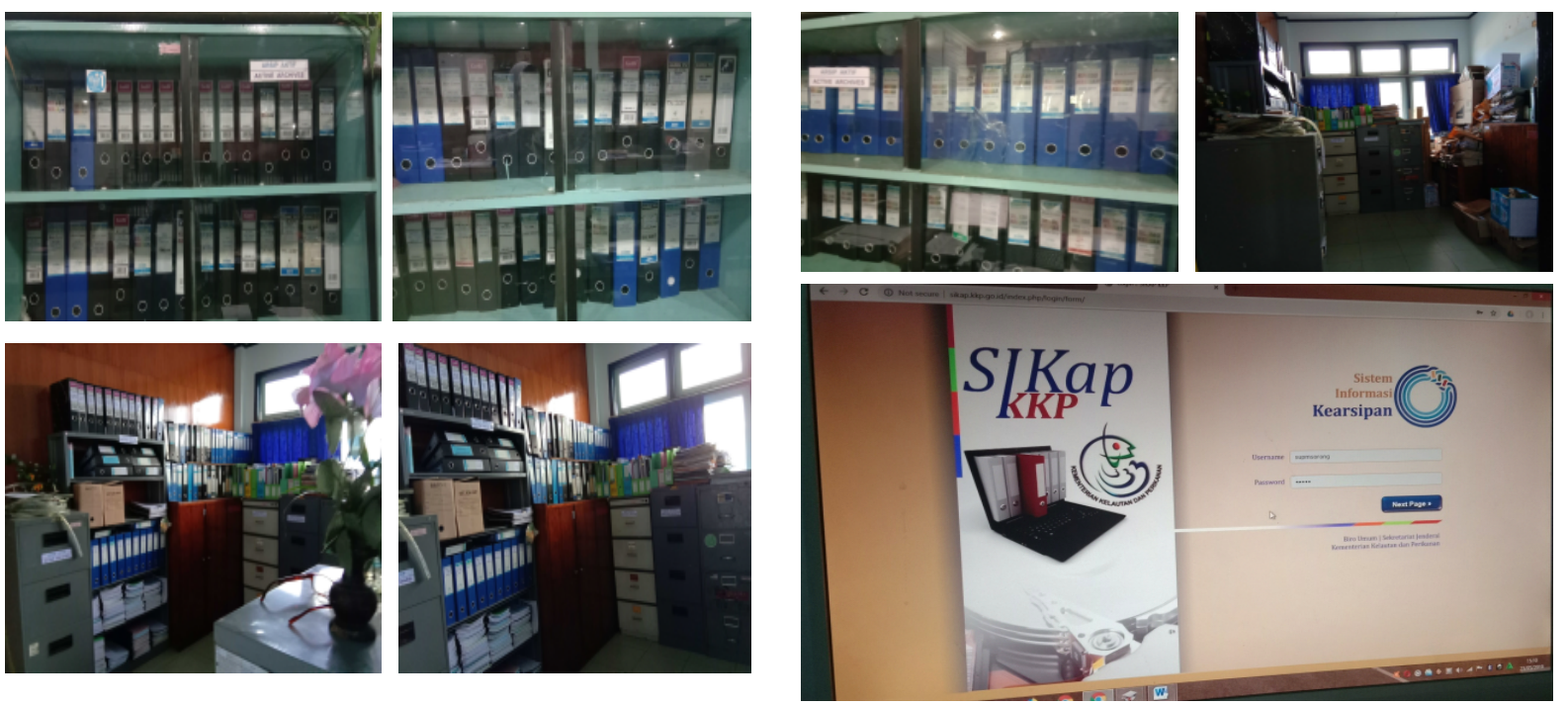